\title{
Sequential enzymatic and electrochemical functionalization of bromocyclohexadienediols: Application to the synthesis of (-)-conduritol C
}

Juana Goulart Stollmaier and Tomáš Hudlický*

Department of Chemistry and Centre for Biotechnology, Brock University, 1812 Sir Isaac Brock Way, St. Catharines, Ontario, L2S 3A1, Canada

thudlicky@brocku.ca

\section{Abstract}

cis-Diene diol obtained from the microbial oxidation of bromobenzene was used as a substrate for the chemoenzymatic acetylation and epoxidation with lipases. The model studies showed that the regiochemistry of the acetylation is solvent-dependent. The chemoenzymatic epoxidation followed the expected regiochemistry when compared to the chemical epoxidation with $m$-CPBA, but with the unexpected formation of bromoconduritol-C, an important intermediate whose electrochemical reduction led to the synthesis of (-)-conduritol-C. Experimental and spectral data are provided for all new compounds.

Keywords: enzymatic dihydroxylation, lipases, acetylation, epoxidation, narciclasine, conduritol C

\section{Introduction}

For more than 30 years, arene cis-dihydrodiols obtained from the whole-cell fermentation of aromatics by $E$. coli JM109 (pDTG601A) ${ }^{1}$ have been used as building blocks in natural product synthesis. The enantiopure diols have been converted to morphine derivatives, cyclitols, sesquiterpenes, the cytotoxic Amaryllidaceae alkaloids, and other complex natural products. ${ }^{2}$ This biooxidation process has proven to be scalable and efficient within green chemistry metrics, and it represents a good example of how biocatalysis can be utilized as a potentially sustainable tool in organic synthesis.

Biocatalysis relies on the use of whole microorganisms or isolated enzymes and the tendency of enzymes to control the environment of the reaction rather than the reaction itself to provide outstanding enantio-, stereo- and regioselectivities in fewer steps than traditional chemical strategies. ${ }^{3}$ By investigating and adding unconventional methods (e.g. biocatalysis, preparative electrochemistry ${ }^{2 \mathrm{a}}$ to previously known synthetic routes unexpected results can be attained and shorter synthetic routes can be achieved.

With this reasoning we considered sequential biotransformations applied to one of the ubiquitously used cis-diols, namely bromocyclohexadienediol 2, which is obtained in high yields ( $>9 \mathrm{~g} / \mathrm{L})$ from the 
dihydroxylation of bromobenzene $1,{ }^{4}$ Scheme 1 . This compound was submitted as a substrate for investigation of lipase-catalyzed acetylation under mild conditions using Amano PS lipase immobilized in diatomite and for chemoenzymatic epoxidation using Candida antarctica lipase (CAL). (Scheme 1) Each of these studies provided valuable results and added new options to the repertoire of reactions that could be applied to the homochiral diols such as $\mathbf{2}$.

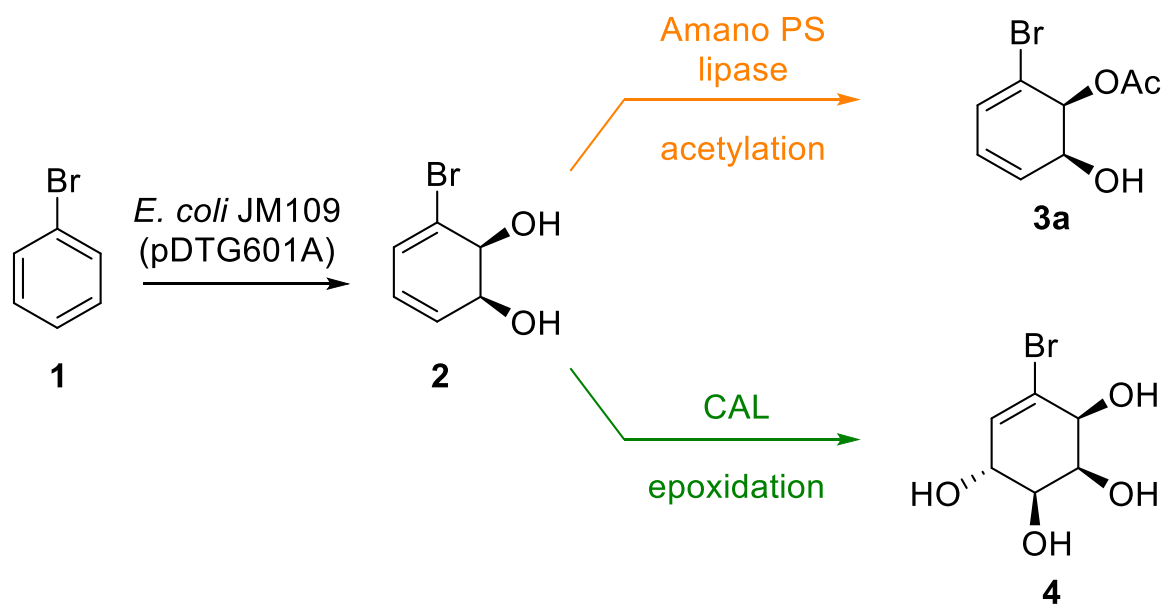

Scheme 1. Chemoenzymatic reactions investigated in this work.

In this work we report the results of chemoenzymatic acetylation of diols in organic media and a short synthesis of (-)-conduritol $\mathrm{C}$ by a chemoenzymatic cascade followed by electrochemical reduction of a vinyl bromide. The synthesis of conduritol was subjected to efficiency metric evaluation $^{5,6}$ in comparison to previous chemical syntheses. The lipase-catalyzed acetylation was also extended to acetylation of the cytotoxic natural product narciclasine.

\section{Results and discussion}

a) Lipase-catalyzed acetylation of 2<smiles>O[C@H]1C=CC=C(Br)[C@H]1O</smiles>

2

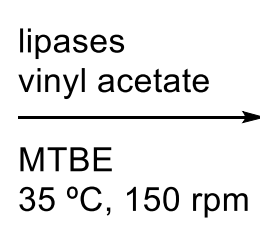

$35^{\circ} \mathrm{C}, 150 \mathrm{rpm}$<smiles>[R2]C1C=CC=C(Br)C1[R2]</smiles>

$$
\begin{aligned}
& 3 a R_{1}=O A c ; R_{2}=O H \\
& \text { 3b } R_{1}=O H ; R_{2}=O A c \\
& 3 c R_{1}=O A c ; R_{2}=O A c
\end{aligned}
$$

Scheme 2. Acetylation of bromodiol (2) catalyzed by AmanoPS immobilized in diatomite.

Screening of lipases. Initial conditions similar to a previously reported acetylation methodology ${ }^{7}$ were used. Three out of nine lipases showed promising activity toward the acetylation of 2: Lipases from Pseudomonas fluorescens (AmanoPF, 20,000 U/g); Burkholderia cepacia (AmanoIM, $500 \mathrm{U} / \mathrm{g}$ ) and 
immobilized in diatomite (AmanoPS-d, $500 \mathrm{U} / \mathrm{g}$ ). The other lipases that were tested are listed in Supporting Information Section I, Part A.

Effect of mass of catalyst and equivalents of acyl donor. The influence of the amount of lipase was evaluated with an initial fixed value at $10 \mathrm{mg} / \mathrm{mL}$ with variation in the number of equivalents of acyl donor. The best results are shown in Table 1 (For details and complete results see Supporting Information Section I, Part B). AmanoIM and AmanoPS-d have similar activities with the same fixed load of active enzyme, while the activity for AmanoPF is approximately 40-fold higher. For the tested lipases, there was an increase in the overall conversion when two equivalents $(1.0 \mathrm{mmol})$ of vinyl acetate were used, but the selectivity between $\mathbf{3 a}$ and $\mathbf{3 b}$ was still low.

Table 1. Analysis of varying amount of acyl donor in chemoenzymatic acetylation. Reaction conditions: $2(0.5 \mathrm{mmol})$, vinyl acetate $(0.5-1.0 \mathrm{mmol})$, lipase $(100 \mathrm{mg})$, Methyl tert-butyl ether (MTBE) $(10 \mathrm{~mL}), 24 \mathrm{~h}, 35{ }^{\circ} \mathrm{C}, 150 \mathrm{rpm}$. Conversion values calculated with ${ }^{1} \mathrm{H}-\mathrm{NMR}$

\begin{tabular}{|c|c|c|c|c|c|c|}
\hline Entry & Lipase & $\begin{array}{c}\text { Vinyl acetate } \\
\text { (mmol) }\end{array}$ & $\begin{array}{c}\text { Overall } \\
\text { Conversion }\end{array}$ & $3 \mathbf{a}$ & $3 b$ & $3 c$ \\
\hline 1 & \multirow{2}{*}{ AmanoIM } & 0.5 & $22 \%$ & $64 \%$ & $36 \%$ & - \\
\hline 2 & & 1.0 & $90 \%$ & $49 \%$ & $46 \%$ & $5 \%$ \\
\hline 3 & \multirow{2}{*}{ AmanoPF } & 0.5 & $38 \%$ & $69 \%$ & $31 \%$ & - \\
\hline 4 & & 1.0 & $51 \%$ & $75 \%$ & $25 \%$ & - \\
\hline 5 & \multirow{2}{*}{ AmanoPS-d } & 0.5 & $32 \%$ & $58 \%$ & $42 \%$ & - \\
\hline 6 & & 1.0 & $90 \%$ & $49 \%$ & $46 \%$ & $5 \%$ \\
\hline
\end{tabular}

A uniform trend among the results presented in Table 1 was not observed. For the second round of experiments the volume of the reaction mixture was lowered from $10 \mathrm{~mL}$ of tert-butyl methyl ether (MTBE) to $5 \mathrm{~mL}$ with variable equivalents of vinyl acetate. The main results are shown in Table 2. (For details and complete results see Supporting Information Section I, Part B)

Table 2. Analysis of varying amount of acyl donor in chemoenzymatic acetylation. Reaction conditions: $2(0.5 \mathrm{mmol})$, vinyl acetate $(0.5-1.5 \mathrm{mmol})$, lipase $(100 \mathrm{mg})$, Methyl tert-butyl ether (MTBE) $(5 \mathrm{~mL}), 24 \mathrm{~h}, 35^{\circ} \mathrm{C}, 150 \mathrm{rpm}$. Conversion values calculated with ${ }^{1} \mathrm{H}-\mathrm{NMR}$

\begin{tabular}{|c|c|c|c|c|c|c|}
\hline Entry & Lipase & $\begin{array}{c}\text { Vinyl acetate } \\
\text { (mmol) }\end{array}$ & Overall conversion & $\mathbf{3 a}$ & $\mathbf{3 b}$ & $3 c$ \\
\hline 7 & \multirow{2}{*}{ AmanoIM } & 1.0 & $>95 \%$ & $48 \%$ & $32 \%$ & $20 \%$ \\
\hline 8 & & 1.5 & $>95 \%$ & $49 \%$ & $33 \%$ & $18 \%$ \\
\hline 9 & \multirow{2}{*}{ AmanoPF } & 1.0 & $76 \%$ & $73 \%$ & $27 \%$ & - \\
\hline 10 & & 1.5 & $78 \%$ & $74 \%$ & $26 \%$ & - \\
\hline 11 & \multirow{2}{*}{ AmanoPS-d } & 1.0 & $>95 \%$ & $39 \%$ & $21 \%$ & $40 \%$ \\
\hline 12 & & 1.5 & $>95 \%$ & $49 \%$ & $32 \%$ & $19 \%$ \\
\hline
\end{tabular}

When the volume of the reaction mixture is decreased while keeping the same relative concentration of the substrate, acyl donor and lipases, AmanoIM and AmanoPS-d showed full overall conversion. AmanoIM is less selective and less sensitive to variation of the concentration of vinyl 
acetate, while AmanoPF had the best selectivity towards formation of 2, but without total consumption of starting material. AmanoPS-d was selected for further studies.

By using more concentrated organic media we observed the formation of diacetate $\mathbf{3 c}$ and complete consumption of starting material. To investigate the source of formation of diacetate $\mathbf{3 c}$, the concentrated crude product from entry 12 was purified by column chromatography and two mixtures of $\mathbf{3 a}$ and $\mathbf{3 b}(1: 1)$ were resubmitted in the shaker with conditions from entry 9 . The first flask was removed from the shaker after $24 \mathrm{~h}$, and a mixture of $\mathbf{3 a}(55 \%), \mathbf{3 b}(14 \%)$ and $\mathbf{3 c}(30 \%)$ was observed through ${ }^{1} \mathrm{H}-\mathrm{NMR}$. The second flask was removed after $48 \mathrm{~h}$, and the mixture contained $\mathbf{3 a} \mathbf{a}(41 \%), \mathbf{3 b}$ $(12 \%)$ and $\mathbf{3 c}(46 \%)$. The monoacetate $\mathbf{3 b}$ appears to be the main substrate for the formation of diacetate 3c.

Effect of solvent. To better understand the effect of biocompatibility of a few organic solvents in the acetylation reaction, two solvents and a mixture of solvents were selected with different logarithm of the partition coefficient $(\log P) .{ }^{8}$ Acetonitrile $(\mathrm{MeCN})(\log P=-0.33)$, MTBE $(\log P=1.24)$, and a 4:1 mixture of $n$-hexane $(\log P=3.5)$ tetrahydrofuran (THF) $(\log P=0.46)$ were selected. An increase in selectivity was observed toward the formation of 3a when MTBE was switched for MeCN, but with a decrease in the overall conversion. The solvent system $n$-hexane:THF 4:1 presented low selectivity in the acetylation of $\mathbf{2}$ and is highly dependent on the concentration of vinyl acetate. Because of the observed trend, both $\mathrm{MeCN}$ and MTBE were selected for further investigations. (For details and complete results see Supporting Information Section I, Part C)

Because of the intramolecular acyl migration from C-2 to C-3, it is not possible to purify 3a and $\mathbf{3 b}$ by column chromatography. The crude product containing a mixture of starting material and products 3a and $\mathbf{3 b}$ was treated with $\mathrm{TBSCl}$ and compound $\mathbf{6}$ was isolated as the major product.<smiles>[R]C1C=CC=C(Br)C1[R7]</smiles>

2: $\mathrm{R}_{1}=\mathrm{OH} ; \mathrm{R}_{2}=\mathrm{OH}$ 3a: $R_{1}=O A c ; R_{2}=O H$ 3b: $\mathrm{R}_{1}=\mathrm{OH} ; \mathrm{R}_{2}=\mathrm{OAC}$
TBSCI, im<smiles>CCOc1ccccc1OCCO</smiles>
$0^{\circ} \mathrm{C}$ to rt

Scheme 3. TBS protection of a mixture of $\mathbf{2}, \mathbf{3 a}$ and $\mathbf{3 b}$.

An acyl migration study was performed by filtering and concentrating the crude product obtained from the chemoenzymatic acetylation in $\mathrm{MeCN}$ and submitting it with a fresh load of solvent. 
After a period of $24 \mathrm{~h}$, acyl migration was observed as there was a $11 \%$ conversion from $\mathbf{3 a}$ to $\mathbf{3 b}$. However, further acyl migration studies using imidazole or other suitable bases were not performed.

Effect of temperature. Temperature can often be a key factor in reactions catalyzed by enzymes. ${ }^{9}$ To evaluate the effect of temperature in the acetylation of bromodiene diol $\mathbf{2}$, reactions were performed using $\mathrm{T}=20^{\circ} \mathrm{C}$ and $\mathrm{T}=45^{\circ} \mathrm{C}$. (For details and complete results see Supporting Information Section I, Part D)

Effect of co-solvents. For the subsequent application of narciclasine as a substrate for the chemoenzymatic acetylation, DMSO $(\log P=-1.3)$ and dimethylformamide (DMF) $(\log P=-0.829)$ were evaluated as co-solvents in the model studies, since these solvents are capable of solubilizing narciclasine. Using the two standard MTBE/MeCN conditions, no conversion to any desired product was obtained with DMSO as a co-solvent. However, overall conversions of $31 \%$ (3a (71\%) and $\mathbf{3 b}$ (29\%)) and 37\% (3a (78\%) and 3b (22\%)) with MTBE:DMF (4:1) and MeCN:DMF (4:1) respectively were observed.

\section{b) Lipase-catalyzed acetylation of narciclasine.}

The reaction conditions for the acetylation of narciclasine were kept similar to the previous study, but with longer reaction time of $72 \mathrm{~h}$. After purification, we observed different selectivity than that in the model study regarding the solvents. The reaction in MTBE:DMF was selective in acylating the C-2 position of narciclasine and trace amounts of acylated C-3 and C-4 products were also detected. (Scheme 4) The reaction with MeCN:DMF is less selective towards acetylation of the C-2 position because it was observed the formation of $\mathrm{C}-3 / \mathrm{C}-4$ monoacetate derivatives of narciclasine. The observed selectivity could be related to the allylic nature of the C-2 position, similar to both allylic alcohols present in the model study with bromodiene diol. No acetylation occurred at the phenolic alcohol at C-7 position, presumably because of the strong H-bond with the neighboring amide.

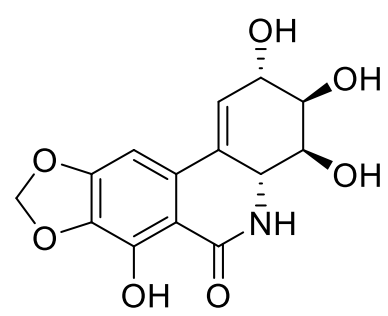

7

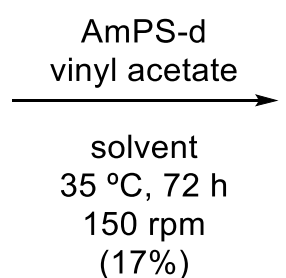

$(17 \%)$<smiles>CC(=O)OC1C=C2c3cc4c(c(O)c3C(=O)N[C@H]2[C@H](O)[C@@H]1O)OCO4</smiles>

8

Scheme 4. Chemoenzymatic acetylation of narciclasine. Reaction conditions: 7 (0.16 mmol), vinyl acetate (1.0 - $1.5 \mathrm{mmol})$, AmanoPS-d (100 mg), MTBE:DMF (4:1) / MeCN:DMF (4:1) (5 mL), 72h,

c) Epoxidation of bromodienediol 2 $35^{\circ} \mathrm{C}, 150 \mathrm{rpm}$. 
Diol 2 was tested as a potential substrate for a chemoenzymatic epoxidation. Chemoenzymatic epoxidations catalyzed by lipases are known to promote the generation of a peracid in situ through a cascade reaction, minimizing hazardous risks of handling peracids in stoichiometric ratios. ${ }^{10}$ Following a previously reported epoxidation methodology, ${ }^{11}$ a few parameters were tested in a similar way to the acetylation study.

Candida antarctica lipase (CAL) and lipase-B (CALB) were selected for the epoxidations and the initial tests showed that the organic solvent and temperature are key parameters for improving the conversion values. (For details and complete results see Supporting Information Section II, Part A). Surprisingly, the syn-epoxide 9 was not observed in the crude product (via ${ }^{1} \mathrm{H}-\mathrm{NMR}$ ) after full consumption of starting material, and upon purification of the crude product, compound $\mathbf{4}$ was obtained in $13 \%$ yield, the remaining mass balance being unidentified decomposition products. (Scheme 5)

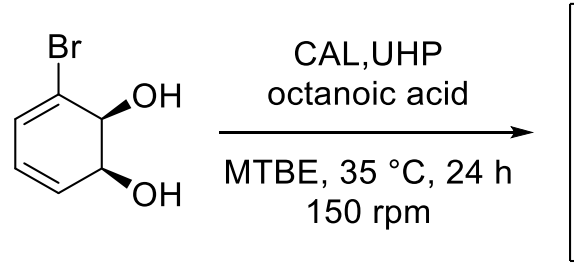

2<smiles>O[C@@H]1[C@@H]2O[C@@H]2C=C(Br)[C@@H]1O</smiles>

9

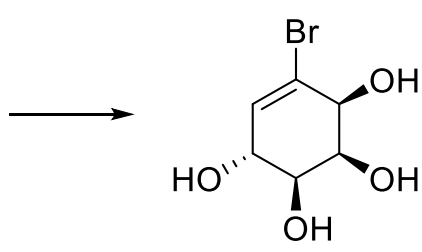

4

Scheme 5. Formation of tetraol $\mathbf{4}$ during chemoenzymatic epoxidation of $\mathbf{2}$.

Protection of diol 2 yielded acetonide 10, which was further used as substrate for the chemoenzymatic epoxidation using the previously reported conditions. A 35\% conversion was observed for the anti-epoxide 11, formed as a result of the steric hindrance of the acetonide moiety. (Scheme 6) Epoxide 11 is stable and was purified by column chromatography without the opening observed in the syn-isomer.

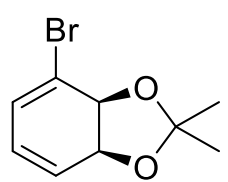

10

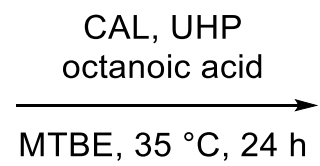

$150 \mathrm{rpm}$

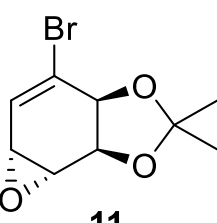

11

Scheme 6. Chemoenzymatic epoxidation of $\mathbf{1 0}$ and formation of anti-epoxide $\mathbf{1 1}$

The diacetate $\mathbf{3 c}$ obtained from the chemoenzymatic acetylation of $\mathbf{1}$ was used in two different approaches to the synthesis of epoxides. By using standard methods with $m$-CPBA, a 2:1 mixture of anti- and syn-epoxides 12a and 12b was obtained, with compound 12b quickly degrading. When the chemoenzymatic epoxidation of $\mathbf{3 c}$ was performed, $19 \%$ conversion was observed for $\mathbf{1 2 a}$, while no conversion was observed for $\mathbf{1 2 b}$. The rest of the mass balance was recovered starting material. (Scheme 7). (For details and complete results see Supporting Information Section II, Part A). 


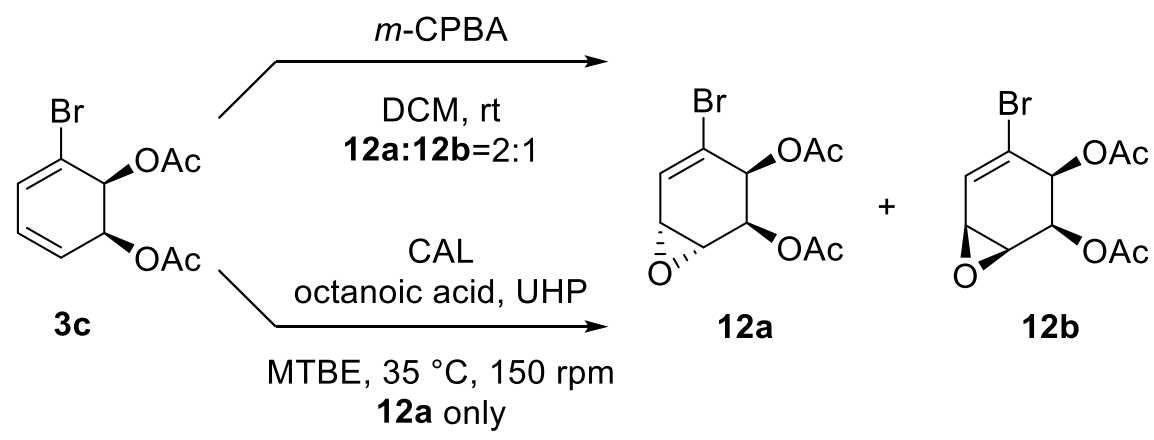

Scheme 7. Comparison between chemical and chemoenzymatic epoxidation of $\mathbf{3 c}$

\section{d) Electrochemical reduction of 4 .}

A methodology for preparative electrochemistry was adapted from a procedure previously published, ${ }^{12}$ replacing the mercury pool with a glassy carbon electrode in a "greener" manner and alternating the polarity of the electrodes to reduce the adsorption on the surface of the electrodes. The constant voltage electrolysis of bromo-conduritol C 4 resulted in a 54\% yield of (-)-conduritol C 13. (Scheme 8)<smiles>OC1C(Br)=C[C@@H](O)C(O)C1O</smiles>

4

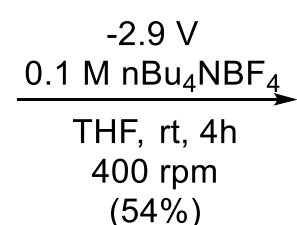

$(54 \%)$<smiles>OC1[C@H](O)C=C[C@H](O)[C@H]1O</smiles>

13

Scheme 8. Preparative electrochemical reduction of 4.

\section{Conclusions}

The chemoenzymatic acetylation and epoxidation were performed under mild conditions. The organic medium had the greatest influence on conversions and selectivity. For the acetylation reactions the regioselectivity was initially considered to be influenced only by the lipase, but it was later shown that some migration of the acetyl groups occurred in solution and/or during purification by chromatography. For the epoxidation of the free diol, the release of water in the catalytic cascade reaction performed by the lipase is sufficient to promote opening of the epoxide and formation of the bromo conduritol, but in low yield. The same effect is not observed when the diol moiety is protected, and the reaction follows the stereochemistry expected from standard chemical epoxidations. The overall yield starting from bromodiene diol is $7 \%$, but there is opportunity to improve the yield of the chemoenzymatic epoxidation, as the standard conditions can be reevaluated and enhanced. Regardless, an old methodology for preparative electrochemistry of conduritol derivatives was adapted for bromoconduritol $\mathrm{C}$ and updated for greener standards. We believe that this route represents a potentially 
efficient synthesis of a valuable building block. The E-factor for this preparation cannot be contextualized as there are no alternate routes from the same starting material.

\section{Experimental section}

\subsection{General}

Analytical thin-layer chromatography was performed using silica gel $60-\mathrm{F}_{254}$ plates. IR spectra were recorded as neat samples. All ${ }^{1} \mathrm{H}-\mathrm{NMR}$ spectra were recorded at ambient temperature using Bruker Avance AV 300 (300 MHz) or Bruker Avance AV 600 (600 MHz) spectrometer. All ${ }^{13}$ C-NMR spectra were recorded at ambient temperature using Bruker Avance AV $300(75 \mathrm{MHz})$ or Bruker Avance AV $600(150 \mathrm{MHz})$ spectrometer. Data are reported as $(\mathrm{s}=$ singlet, $\mathrm{d}=$ doublet, $\mathrm{t}=$ triplet, $\mathrm{q}$ $=$ quartet, $\mathrm{m}=$ multiplet, $\mathrm{br}=$ broad) coupling constants in $\mathrm{Hz}$, integration. Specific rotation measurements are given in $\operatorname{deg} . \mathrm{cm}^{3} \cdot \mathrm{g}^{-1} \cdot \mathrm{dm}^{-1}$. Mass spectra and high-resolution mass spectra were performed by the analytical division at Brock University. Electrochemical reactions and cyclic voltammetry experiments were carried out in an IKA ElectraSyn 2.0. CV curves were recorded using a three-electrode scheme: The working electrode was a CV glassy carbon electrode and a platinum electrode served as counter electrode. $\mathrm{Ag} / \mathrm{AgCl}$ was used as the reference electrode with a $3 \mathrm{M} \mathrm{NaCl}$ as reference electrolyte. The preparative electrochemistry was performed using a three-electrode scheme: The working electrode was a glassy carbon electrode $(\mathrm{d}=3 \mathrm{~mm})$ and a platinum electrode served as counter electrode. $\mathrm{Ag} / \mathrm{AgCl}$ was used as the reference electrode with a $3 \mathrm{M} \mathrm{NaCl}$ as reference electrolyte.

\subsection{Chemoenzymatic acetylation}

In a typical chemoenzymatic acetylation reaction, a mixture of bromodiene diol 2 (95 mg, 0.5 mmol), vinyl acetate $(0.15 \mathrm{~mL}, 1.5 \mathrm{mmol})$ and AmanoPS-d $(100 \mathrm{mg})$ in methyl tert-butyl ether $(5 \mathrm{~mL})$, or acetonitrile $(5 \mathrm{~mL})$ was stirred at $150 \mathrm{rpm}$, at $35^{\circ} \mathrm{C}$, for $24 \mathrm{~h}$. The crude mixture was filtered to remove the catalyst and concentrated in vacuo to afford a mixture of $\mathbf{3 a}$ and $\mathbf{3 b}$ (and $\mathbf{3} \mathbf{c}$ when specified) as a yellow oil.

\subsection{1. (1S,6S)-2-bromo-6-hydroxycyclohexa-2,4-dien-1-yl acetate (3a)}

${ }^{1} \mathbf{H}$ NMR $\left(300 \mathrm{MHz}, \mathrm{CDCl}_{3}\right): \delta_{\mathrm{ppm}} 6.51(\mathrm{dd}, J=5.5,1.1 \mathrm{~Hz}, 1 \mathrm{H}), 5.93-5.86(\mathrm{~m}, 2 \mathrm{H}), 5.59$ $(\mathrm{d}, J=6.7 \mathrm{~Hz}, 1 \mathrm{H}), 4.68(\mathrm{dt}, J=6.7,2.0 \mathrm{~Hz}, 1 \mathrm{H}), 2.16(\mathrm{~s}, 3 \mathrm{H})$.

5.2.2. (1S,6S)-5-bromo-6-hydroxycyclohexa-2,4-dien-1-yl acetate (3b)

${ }^{1} \mathbf{H}$ NMR $\left(300 \mathrm{MHz}, \mathrm{CDCl}_{3}\right): \delta_{\mathrm{ppm}} 6.39(\mathrm{dd}, J=5.2,0.9 \mathrm{~Hz}, 1 \mathrm{H}), 5.94-5.80(\mathrm{~m}, 2 \mathrm{H}), 5.48$ (ddd, $J=6.2,3.0,0.9 \mathrm{~Hz}, 1 \mathrm{H}), 4.43(\mathrm{~d}, J=6.2 \mathrm{~Hz}, 1 \mathrm{H}), 2.11(\mathrm{~s}, 3 \mathrm{H})$. 


\subsection{3. (1S,2S)-3-bromocyclohexa-3,5-diene-1,2-diyl diacetate (3c)}

Diene diol 2 ( $2.0 \mathrm{~g}, 0.01 \mathrm{~mol})$ was solubilized in dichloromethane $(15 \mathrm{~mL})$ and cooled to $0{ }^{\circ} \mathrm{C}$. Triethylamine (4 mL, $0.03 \mathrm{mmol}$ ), 4-dimethylaminopyridine (DMAP, cat. amount, 3 crystals) was added to the solution, followed by dropwise addition of acetic anhydride ( $3 \mathrm{~mL}, 0.03 \mathrm{mmol})$. After 1 $\mathrm{h}$, the reaction mixture was quenched with $\mathrm{NaHCO}_{3}(15 \mathrm{~mL})$ and extracted with dichloromethane ( $3 \times 15 \mathrm{~mL})$. The organic phases were combined and dried over $\mathrm{MgSO}_{4}$, filtered and concentrated in vacuo. The residue was purified by column chromatography on deactivated silica gel (10\%) (hexanes:EtOAc (6:1)) to yield diacetate $3 \mathbf{c}$ as a yellow oil (1.8 g, $65 \%)$.

3c: $[\boldsymbol{\alpha}]_{\mathbf{D}}^{\mathbf{2 1}}=-71.78(\mathrm{c} 1.0, \mathrm{MeCN}) ;{ }^{1} \mathbf{H} \mathbf{~ N M R}\left(300 \mathrm{MHz}, \mathrm{CDCl}_{3}\right) \delta_{\mathrm{ppm}} 6.55(\mathrm{dd}, J=5.7,0.6 \mathrm{~Hz}, 1 \mathrm{H})$, 5.97 (ddd, $J=9.5,5.8,1.6 \mathrm{~Hz}, 1 \mathrm{H}), 5.84$ (ddt, $J=9.6,2.4,0.7 \mathrm{~Hz}, 1 \mathrm{H}), 5.73-5.70$ (m, 2H), 2.11 (s, 3H), 2.06 (s, 3H); ${ }^{13} \mathrm{C}$ NMR (75 MHz, $\left.\mathrm{CDCl}_{3}\right) \delta_{\mathrm{ppm}} 170.21,170.12,129.56,125.63,124.98,120.32$, 70.03, 69.04, 20.89, 20.80; IR $v_{\max }:$ 1739, 1369, 1208, 1068, 1015, 734, 596.

\subsection{TBS-protection}

5.3.1. (1S,6S)-2-bromo-6-((tert-butyldimethylsilyl)oxy)cyclohexa-2,4-dien-1-ol (5) ${ }^{13}$ Imidazole (200 mg, $2.9 \mathrm{mmol})$ and TBSCl (450 mg, $3.0 \mathrm{mmol})$ were added to a magnetically stirred cold $\left(0{ }^{\circ} \mathrm{C}\right)$ solution of diol $2(500 \mathrm{mg}, 2.6 \mathrm{mmol})$ in DMF $(10 \mathrm{~mL})$ maintained under an atmosphere of nitrogen. After $16 \mathrm{~h}$ the reaction mixture was diluted with $\mathrm{Et}_{2} \mathrm{O}(20 \mathrm{~mL})$ and washed with brine $(3 \times 15 \mathrm{~mL})$. The combined organic extracts were then dried with $\mathrm{MgSO}_{4}$, filtered and concentrated in vacuo to give a pale-yellow oil. The crude product was purified by flash column chromatography on deactivated silica gel $(10 \%)$ (hexane:EtOAc $(6: 1 \rightarrow 4: 1))$ to yield $5(363 \mathrm{mg}, 45 \%)$.

5: $[\boldsymbol{\alpha}]_{\mathbf{D}}^{\mathbf{2 1}}=44.60(\mathrm{c} 0.5, \mathrm{MeCN}) ;{ }^{\mathbf{1}} \mathbf{H} \mathbf{N M R}\left(300 \mathrm{MHz}, \mathrm{CDCl}_{3}\right) \delta_{\mathrm{ppm}} 6.37(\mathrm{dd}, J=4.1,2.5 \mathrm{~Hz}, 1 \mathrm{H}), 5.78$ $(\mathrm{d}, J=3.7 \mathrm{~Hz}, 2 \mathrm{H}), 4.57(\mathrm{~d}, J=6.3 \mathrm{~Hz}, 1 \mathrm{H}), 4.14(\mathrm{dd}, J=6.2,4.6 \mathrm{~Hz}, 1 \mathrm{H}), 2.77(\mathrm{~d}, J=4.7 \mathrm{~Hz}, 1 \mathrm{H})$, $0.92(\mathrm{~s}, 9 \mathrm{H}), 0.13(\mathrm{~s}, 6 \mathrm{H}) ;{ }^{13} \mathbf{C} \mathbf{N M R}\left(75 \mathrm{MHz}, \mathrm{CDCl}_{3}\right) \delta_{\mathrm{ppm}} 129.65,127.10,125.64,123.57,77.16$, 72.80, 70.75, 26.04, 25.90, 18.30, -4.40, -4.71; IR $v_{\max }: 3548,2952,2856,1571,1470,1389,1253$, 1059, 834, 776, 676, $647 \mathrm{~cm}^{-1}$; HRMS (EI) Calcd for $\mathrm{C}_{12} \mathrm{H}_{21} \mathrm{BrO}_{2} \mathrm{Si}\left(\mathrm{M}^{+}\right)$: 304.0494, found 304.0492; LRMS (ESI) found $322\left[\mathrm{M}+\mathrm{NH}_{4}\right]^{+}, 327[\mathrm{M}+\mathrm{Na}]^{+}, 342.9[\mathrm{M}+\mathrm{K}]^{+}$.

\subsection{2. (1S,6S)-2-bromo-6-((tert-butyldimethylsilyl)oxy)cyclohexa-2,4-dien-1-yl acetate (6)}

A similar procedure was repeated using a crude mixture of $\mathbf{2}, \mathbf{3 a}$ and $\mathbf{3 b}(285 \mathrm{mg}$ ) from a chemoenzymatic acetylation solubilized in DMF $(10 \mathrm{~mL})$. The solution was cooled to $0{ }^{\circ} \mathrm{C}$ and imidazole (200 mg, $2.9 \mathrm{mmol})$ and TBSCl (400 mg, $2.6 \mathrm{mmol})$ were added. After $16 \mathrm{~h}$ the reaction mixture was diluted with $\mathrm{Et}_{2} \mathrm{O}(20 \mathrm{~mL})$ and washed with brine $(3 \times 15 \mathrm{~mL})$. The combined organic extracts were then dried with $\mathrm{MgSO}_{4}$, filtered and concentrated in vacuo to give a pale-yellow oil. The 
crude product was purified by flash column chromatography on deactivated silica gel (10\%) (hexane:EtOAc $(10: 1 \rightarrow 4: 1))$ to yield $6(125 \mathrm{mg})$.

6: $[\boldsymbol{\alpha}]_{\mathbf{D}}^{21}=-78.16(\mathrm{c} 1.0, \mathrm{MeCN}) ;{ }^{1} \mathbf{H}$ NMR $\left(300 \mathrm{MHz}, \mathrm{CDCl}_{3}\right) \delta_{\mathrm{ppm}} 6.49(\mathrm{dd}, J=4.1,2.5 \mathrm{~Hz}, 1 \mathrm{H}), 5.82$ $(\mathrm{d}, J=3.3 \mathrm{~Hz}, 2 \mathrm{H}), 5.56(\mathrm{~d}, J=6.8 \mathrm{~Hz}, 1 \mathrm{H}), 4.68(\mathrm{~d}, J=6.8 \mathrm{~Hz}, 1 \mathrm{H}), 2.10(\mathrm{~s}, 3 \mathrm{H}), 0.89$ (s, 9H), 0.12 $(\mathrm{s}, 3 \mathrm{H}), 0.09$ (s, 3H); ${ }^{13} \mathbf{C}$ NMR $\left(75 \mathrm{MHz}, \mathrm{CDCl}_{3}\right) \delta_{\mathrm{ppm}} 170.17,131.78,129.89,122.46,120.31,72.17$, 70.01, 25.84, 20.96, 18.29, -4.88, -5.02; IR $v_{\max }: 2927,2855,1736,1740,1222,1119,1097,827,784$, $667 \mathrm{~cm}^{-1}$; HRMS (EI) Calcd for $\mathrm{C}_{14} \mathrm{H}_{23} \mathrm{BrO}_{3} \mathrm{Si}\left(\mathrm{M}^{+}\right)$: 346.0600, found 346.0594; LRMS (ESI) found $364\left[\mathrm{M}+\mathrm{NH}_{4}\right]^{+}, 369[\mathrm{M}+\mathrm{Na}]^{+}, 385[\mathrm{M}+\mathrm{K}]^{+}$

\section{4. (2S,3S,4S,4aR)-3,4,7-trihydroxy-6-oxo-2,3,4,4a,5,6-hexahydro-[1,3]dioxolo[4,5-} j]phenanthridin-2-yl acetate $(\mathbf{8})^{14}$

Two reaction mixtures were prepared with $7(50 \mathrm{mg}, 0.16 \mathrm{mmol})$ each, the first with $0.10 \mathrm{~mL}$ (1.0 mmol) of vinyl acetate and $5 \mathrm{~mL}$ of MTBE:DMF (4:1) and the second with $0.15 \mathrm{~mL}$ of vinyl acetate and $5 \mathrm{~mL}$ of MeCN:DMF (4:1). Both had $100 \mathrm{mg}$ of lipase as the biocatalyst. Both reactions were stirred at $150 \mathrm{rpm}$, at $35^{\circ} \mathrm{C}$, for $72 \mathrm{~h}$. The reaction mixtures were combined and concentrated by rotary evaporation and its crude product was purified by flash column chromatography on deactivated silica gel (10\%) (DCM:MeOH (50:1 $\rightarrow 30: 1))$ to obtain the title compound 8 (20 $\mathrm{mg}, 17 \%)$ as a paleyellow solid.

8: $\mathbf{R f}=0.21(\mathrm{DCM}: \mathrm{MeOH} 10: 1) ;{ }^{1} \mathbf{H}$ NMR $\left(300 \mathrm{MHz}, \mathrm{DMSO}-d_{6}\right) \delta_{\mathrm{ppm}} 13.17(\mathrm{~s}, 1 \mathrm{H}), 8.01(\mathrm{~s}, 1 \mathrm{H})$, $6.86(\mathrm{~s}, 1 \mathrm{H}), 6.10(\mathrm{dd}, \mathrm{J}=4.2,2.5 \mathrm{~Hz}, 1 \mathrm{H}), 6.06(\mathrm{~d}, J=1.2 \mathrm{~Hz}, 2 \mathrm{H}), 5.48(\mathrm{~d}, J=4.1 \mathrm{~Hz}, 1 \mathrm{H}), 5.33(\mathrm{~d}$, $J=5.4 \mathrm{~Hz}, 1 \mathrm{H}), 5.17(\mathrm{ddd}, J=4.4,2.9,1.3 \mathrm{~Hz}, 1 \mathrm{H}), 4.22(\mathrm{~d}, J=8.2 \mathrm{~Hz}, 1 \mathrm{H}), 3.78-3.65(\mathrm{~m}, 2 \mathrm{H})$, $2.00(\mathrm{~s}, 3 \mathrm{H}) ;{ }^{13} \mathrm{C}$ NMR $\left(75 \mathrm{MHz}, \mathrm{DMSO}-d_{6}\right) \delta_{\mathrm{ppm}} 169.68,168.92,152.43,144.88,133.97,133.32$, $131.25,119.32,105.78,102.27,96.19,71.00,69.25,69.14,52.76,20.83$. The spectral data were matched and are in agreement with the literature data. ${ }^{14}$

\subsection{Epoxidation}

In a typical chemoenzymatic epoxidation reaction, a mixture of substrate $(2,3 c$ or $10(0.5$ mmol)), urea-hydrogen peroxide (UHP) $(94 \mathrm{mg}, 1.0 \mathrm{mmol})$, octanoic acid (80 $\mu \mathrm{L}, 0.5 \mathrm{mmol})$ and Candida antarctica lipase (CAL) $(10 \mathrm{mg})$ in methyl tert-butyl ether $(5 \mathrm{~mL})$ was stirred at $150 \mathrm{rpm}$, at $35{ }^{\circ} \mathrm{C}$, for $24 \mathrm{~h}$. The crude mixture was filtered for removal of the catalyst and concentrated in vacuo and further analyzed by ${ }^{1} \mathrm{H}-\mathrm{NMR}$.

\subsection{1. (1R,2S,3S,4S)-5-bromocyclohex-5-ene-1,2,3,4-tetraol (4) $)^{15}$}


The crude mixture of 6 batches was combined and filtered for removal of the catalyst, and the flasks were washed with $\mathrm{MeOH}$ to remove product residues and combined with the MTBE filtrate and concentrated in vacuo. The obtained white crude product was adsorbed in $24 \%$ deactivated silica gel and purified by flash column chromatography (EtOAc:Hex:MeOH 8:1:1) to yield tetrol as a white solid 4 (88 mg, 13\%).

4: $[\boldsymbol{\alpha}]_{\mathbf{D}}^{\mathbf{2 2}}=-64.53(\mathrm{c} \mathrm{0.5}, \mathrm{MeOH}) ;$ lit. $^{15}[\boldsymbol{\alpha}]_{\mathbf{D}}^{\mathbf{2 0}}=-50(\mathrm{c} \mathrm{0.01,} \mathrm{MeOH}) ;{ }^{1} \mathbf{H}$ NMR $(600 \mathrm{MHz}, \mathrm{MeOD}) \delta 6.09$ - $6.06(\mathrm{~m}, 1 \mathrm{H}), 4.24(\mathrm{dt}, J=6.5,2.4 \mathrm{~Hz}, 1 \mathrm{H}), 4.20-4.17(\mathrm{~m}, 1 \mathrm{H}), 4.06(\mathrm{dd}, J=3.7,2.0 \mathrm{~Hz}, 1 \mathrm{H}), 3.61$ $(\mathrm{dd}, J=6.8,1.9 \mathrm{~Hz}, 1 \mathrm{H}) . ;{ }^{13} \mathbf{C}$ NMR $(151 \mathrm{MHz}, \mathrm{MeOD}) \delta 133.04,127.66,75.47,73.10,72.84,71.53$; LRMS (ESI+/-) Calcd for $\mathrm{C}_{6} \mathrm{H}_{9} \mathrm{BrO}_{4}[\mathrm{M}]^{+}:$223.9684, found $242\left[\mathrm{M}+\mathrm{NH}_{4}\right]^{+}, 246.9[\mathrm{M}+\mathrm{Na}]^{+}, 262.9$ $[\mathrm{M}+\mathrm{K}]^{+}$. The spectral data were matched and are in agreement with the literature data. ${ }^{15}$

\subsection{2. (3aS,7aS)-4-bromo-2,2-dimethyl-3a,7a-dihydrobenzo[d][1,3]dioxole $(\mathbf{1 0})^{16}$}

Diol 1 (2 g, $0.01 \mathrm{~mol})$ was suspended in DCM (10 mL), and 2,2-DMP (5 mL, $0.04 \mathrm{~mol})$ was added followed by the addition of a catalytic amount of $p$-TSA. The reaction mixture was left stirring for $4 \mathrm{~h}$ at room temperature and the consumption of starting material was checked with TLC (hexane:EtOAc (4:1)). The reaction was quenched with $\mathrm{NaHCO}_{3}$ and extracted with DCM. The combined organic phases were dried with $\mathrm{MgSO}_{4}$ and concentrated on the rotary evaporator. The residue was adsorbed on deactivated silica gel (10\%), and purified by column chromatography (hexane:EtOAc (8:1)) to afford 10 as a colorless oil $(1.43 \mathrm{~g}, 59 \%)$. This compound quickly dimerizes and must be used immediately. Otherwise, it is necessary to keep it stored in solution in the freezer ($\left.13^{\circ} \mathrm{C}\right)$.

10: $\left.[\alpha]_{\mathbf{D}}\right]^{21}=77.08(\mathrm{c} 1.5, \mathrm{MeCN}) ;{ }^{1} \mathbf{H} \mathbf{N M R}\left(300 \mathrm{MHz}, \mathrm{CDCl}_{3}\right) \delta 6.34(\mathrm{~d}, J=6.1 \mathrm{~Hz}, 1 \mathrm{H}), 5.97(\mathrm{~d}, J=$ $9.5 \mathrm{~Hz}, 1 \mathrm{H}), 5.87(\mathrm{dd}, J=9.6,6.0 \mathrm{~Hz}, 1 \mathrm{H}), 4.72(\mathrm{~d}, J=1.7 \mathrm{~Hz}, 2 \mathrm{H}), 1.44(\mathrm{~s}, 2 \mathrm{H}), 1.43(\mathrm{~s}, 3 \mathrm{H}) .{ }^{13} \mathbf{C}$ NMR $\left(75 \mathrm{MHz}, \mathrm{CDCl}_{3}\right) \delta 125.90,124.77,124.53,124.22,106.34,76.01,72.60,26.84,25.08$. The spectral data were matched and are in agreement with the literature data. ${ }^{16}$

5.5.3. (3aS, 5aR,6aR,6bS)-4-bromo-2,2-dimethyl-3a,5a,6a,6b tetrahydrooxireno $\left[2^{\prime}, 3^{\prime}: 3,4\right]$ benzo[1,2-d][1,3]dioxole $(\mathbf{1 1})^{17}$

$75 \mathrm{mg}(0.43 \mathrm{mmol})$ of recrystallized $m$-CPBA was added to a cold solution of $\mathbf{1 0}$ (100 $\mathrm{mg}, 0.43$ $\mathrm{mmol})$ in DCM (5 mL) and left stirring overnight. TLC showed the presence of starting material, so another $35 \mathrm{mg}$ of $m$-CPBA was added to the cold reaction mixture. After $3 \mathrm{~h}$, the reaction was quenched with $\mathrm{NaHCO}_{3}$, extracted with DCM and the combined organic phases were dried with $\mathrm{MgSO}_{4}$ and concentrated. The residue was purified by flash column chromatography with deactivated silica gel (10\%) (hexane:EtOAc (8:1)) to yield 11 as a colorless oil (80 mg, 75\%). 
11: $[\boldsymbol{\alpha}]_{\mathbf{D}}^{21}=95.6(\mathrm{c} \mathrm{0.7}, \mathrm{MeCN}) ;{ }^{1} \mathbf{H} \mathbf{N M R}\left(300 \mathrm{MHz}, \mathrm{CDCl}_{3}\right) \delta 6.47(\mathrm{dd}, J=4.4,1.1 \mathrm{~Hz}, 1 \mathrm{H}), 4.86$ (ddd, $J=6.8,1.8,1.1 \mathrm{~Hz}, 1 \mathrm{H}), 4.41(\mathrm{dd}, J=6.8,0.9 \mathrm{~Hz}, 1 \mathrm{H}), 3.58(\mathrm{dd}, J=3.7,1.9 \mathrm{~Hz}, 1 \mathrm{H}), 3.34-$ $3.30(\mathrm{~m}, 1 \mathrm{H}), 1.45$ (s, 3H), 1.43 (s, 3H). $\left.{ }^{13} \mathbf{C ~ N M R ~ ( 7 5 ~ M H z , ~} \mathrm{CDCl}_{3}\right) \delta 130.01,126.61,111.54,74.24$, $72.74,49.59,48.42,27.63,26.12$. The spectral data were matched and are in agreement with the literature data. ${ }^{17}$

\subsection{4. (1R,2S,3S,6R)-4-bromo-7-oxabicyclo[4.1.0]hept-4-ene-2,3-diyl diacetate (12a)}

$80 \mathrm{mg}(0.46 \mathrm{mmol})$ of recrystallized $m$-CPBA was added to a cold solution of diacetate $\mathbf{3 c}$ (114 mg, $0.46 \mathrm{mmol})$ in DCM (5 mL) and left stirring overnight. The reaction was quenched with $\mathrm{NaHCO}_{3}$, extracted with DCM and the combined organic phases were dried with $\mathrm{MgSO}_{4}$ and concentrated. The residue was purified by flash column chromatography with deactivated silica gel (10\%) (hexane:EtOAc (8:1)) to yield 12a as an opaque oil (28 $\mathrm{mg}, 21 \%)$ and $\mathbf{1 2 b}$ as a yellow solid (14 $\mathrm{mg}$, $10 \%)$. Compound $\mathbf{1 2 b}$ is unstable and quickly decomposes even when kept in the freezer $\left(-15^{\circ} \mathrm{C}\right)$.

12a: $[\boldsymbol{\alpha}]_{\mathbf{D}}^{21}=112.8(\mathrm{c} 0.6, \mathrm{MeCN}) ;{ }^{1} \mathbf{H} \mathbf{N M R}\left(300 \mathrm{MHz}, \mathrm{CDCl}_{3}\right) \delta 6.55(\mathrm{dd}, J=4.3,2.5 \mathrm{~Hz}, 1 \mathrm{H}), 5.79$ (ddd, $J=4.9,3.0,0.5 \mathrm{~Hz}, 1 \mathrm{H}), 5.49(\mathrm{dd}, J=4.9,2.5 \mathrm{~Hz}, 1 \mathrm{H}), 3.48(\mathrm{t}, J=3.5 \mathrm{~Hz}, 1 \mathrm{H}), 3.37(\mathrm{t}, J=3.8$ $\mathrm{Hz}, 1 \mathrm{H}), 2.07$ (s, 3H), 2.06 (s, 3H). ${ }^{13} \mathbf{C}$ NMR (75 MHz, $\left.\mathrm{CDCl}_{3}\right) \delta 170.14,169.31,127.34,125.82$, 66.86, 66.27, 50.87, 48.33, 20.83, 20.64; IR $v_{\max }: 1742,1371,1210,1069,1047,896,597,552,471$ $\mathrm{cm}^{-1}$.

\subsection{5. (1S,2S,3S,6S)-4-bromo-7-oxabicyclo[4.1.0]hept-4-ene-2,3-diyl diacetate (12b)}

12b: $[\boldsymbol{\alpha}]_{\mathbf{D}}^{\mathbf{2 1}}=-230.4(\mathrm{c} 0.6, \mathrm{MeCN}) ;{ }^{1} \mathbf{H} \mathbf{N M R}\left(300 \mathrm{MHz}, \mathrm{CDCl}_{3}\right) \delta 6.65(\mathrm{~d}, J=4.4 \mathrm{~Hz}, 1 \mathrm{H}), 5.82(\mathrm{dd}, J$ $=5.5,2.0 \mathrm{~Hz}, 1 \mathrm{H}), 5.42(\mathrm{dd}, J=5.5,1.2 \mathrm{~Hz}, 1 \mathrm{H}), 3.59-3.54(\mathrm{~m}, 1 \mathrm{H}), 3.46(\mathrm{t}, J=4.4 \mathrm{~Hz}, 1 \mathrm{H}), 2.15$ (s, 3H), 2.08 (s, 3H); ${ }^{13} \mathbf{C}$ NMR (75 MHz, $\left.\mathrm{CDCl}_{3}\right) \delta 170.75,169.97,131.45,123.59,70.30,68.90$, 53.34, 48.20, 20.88, 20.71. IR $v_{\max }: 1743,1368,1229,1206,1051,897,728,552,603 \mathrm{~cm}^{-1}$.

\subsection{Preparative electrochemistry}

5.6.1. (1R,2R,3S,4R)-cyclohex-5-ene-1,2,3,4-tetrol (13) [(-)-conduritol C] $]^{15,18}$

A $0.1 \mathrm{M}$ solution of the charge carrier $n \mathrm{Bu}_{4} \mathrm{NBF}_{4}$ (TBATFB) in $10 \mathrm{~mL}$ of THF was added to the IKA ElectraSyn vial. The solution was purged with an argon stream for 10min. Compound 4 (40 $\mathrm{mg}, 0.17 \mathrm{mmol}$ ) was added in the vial and the vial was closed with the three-electrode scheme. The $\mathrm{CV}$ was done to obtain the reduction potential (-2.9 V) and the $\mathrm{CV}$ electrode was changed to the glassy carbon electrode. The mixture was electrolyzed with constant voltage for $4 \mathrm{~h}$ with the polarity being alternated every $5 \mathrm{~min}$. Upon completion of the reaction, the solvent was evaporated, and the resulting green solid was adsorbed in $10 \%$ deactivated silica gel and purified by flash column chromatography 
(EtOAc to remove most of the charge carrier and EtOAc:MeOH 8:1) to yield (-)-conduritol C 13 (14 $\mathrm{mg}, 54 \%)$ as a white solid.

13: $[\boldsymbol{\alpha}]_{\mathbf{D}}^{21}=-141.13(\mathrm{c} 0.2, \mathrm{MeOH}) *$; lit. $^{15}[\boldsymbol{\alpha}]_{\mathbf{D}}^{20}=-205(\mathrm{c} 0.2, \mathrm{MeOH}) ;{ }^{1} \mathbf{H}$ NMR $(300 \mathrm{MHz}, \mathrm{MeOD}) \delta$ $5.65(\mathrm{dt}, J=10.3,2.0 \mathrm{~Hz}, 1 \mathrm{H}), 5.56(\mathrm{ddd}, J=10.2,3.5,1.8 \mathrm{~Hz}, 1 \mathrm{H}), 4.27(\mathrm{dd}, J=4.5,2.3 \mathrm{~Hz}, 1 \mathrm{H})$, $4.26-4.20(\mathrm{~m}, 1 \mathrm{H}), 4.02(\mathrm{dt}, J=3.5,1.8 \mathrm{~Hz}, 1 \mathrm{H}), 3.53(\mathrm{dd}, J=7.4,2.0 \mathrm{~Hz}, 1 \mathrm{H}) ;{ }^{13} \mathrm{C} \mathrm{NMR}(75 \mathrm{MHz}$, MeOD) $\delta 130.84,130.11,76.20,74.05,70.65,69.57$. * Small amounts of charge carrier still present in the sample. The spectral data were matched and are in agreement with the literature data. ${ }^{18}$

\section{Acknowledgements}

We are grateful to the following agencies for financial support of this work: the Natural Sciences and Engineering Research Council of Canada (NSERC; Idea to Innovation and Discovery Grants), the Canada Research Chair Program, the Canada Foundation for Innovation (CFI), TDC Research, Inc., the TDC Research Foundation, the Ontario Partnership for Innovation and Commercialization (OPIC), and The Advanced Biomanufacturing Centre (Brock University). We thank Dr. Liqun Qui for her help with mass spectrometry.

\footnotetext{
${ }^{1}$ G.J. Zylstra, D.T. Gibson, Toluene degradation by Pseudomonas putida F1. Nucleotide sequence of the todC1C2BADE genes and their expression in Escherichia coli, J. Biol. Chem. 264 (1989) 14940-14946.

${ }^{2}$ For use of these metabolites in synthesis see: a) T. Hudlicky, Benefits of Unconventional Methods in the Total Synthesis of Natural Products, ACS Omega. 3 (2018) 17326-17340. b) E.S. Taher, M.G. Banwell, J.N. Buckler, Q. Yan, P. Lan, The Exploitation of Enzymatically-Derived cis -1,2-Dihydrocatechols and Related Compounds in the Synthesis of Biologically Active Natural Products, Chem. Rec. 18 (2018) 239-264. c) M.G. Banwell, B. Bolte, J.N. Buckler, E.L. Chang, P. Lan, E.S. Taher, L. V. White, A.C. Willis, Chemoenzymatic pathways for the synthesis of biologically active natural products, J. Proc. R. Soc. New South Wales. 149 (2016) 34-50. d) S.E. Lewis, Applications of biocatalytic arene ipso, ortho cisdihydroxylation in synthesis, Chem. Commun. 50 (2014) 2821-2830. e) U. Rinner, 2.9 Chiral Pool Synthesis: Chiral Pool Syntheses from cis-Cyclohexadiene Diols, in: H. Yamamoto, E. Carreira (Eds.), Compr. Chirality, Elsevier, 2012: pp. 240 267. f) D.J.-Y.D. Bon, B. Lee, M.G. Banwell, I.A. Cade, Biocatalytically-derived cis-1,2-dihydrocatechols - enantiopure and versatile building blocks for chemical synthesis., Chim. Oggi. 30 (2012) 22-27. g) T. Hudlicky, J.W. Reed, Celebrating 20 years of Synlett - Special account on the merits of biocatalysis and the impact of arene cis-dihydrodiols on enantioselective synthesis, Synlett. (2009) 0685-0703. h) T. Hudlicky, J.W. Reed, Applications of biotransformations and biocatalysis to complexity generation in organic synthesis, Chem. Soc. Rev. 38 (2009) 3117. i) D.R. Boyd, T.D.H. Bugg, Arene cis-dihydrodiol formation: from biology to application, Org. Biomol. Chem. 4 (2006) 181-192. j) R.A. Johnson, Microbial Arene Oxidations, in: Org. React., John Wiley \& Sons, Inc., Hoboken, NJ, USA, 2004: pp. 117-264. k) M.G. Banwell, A.J. Edwards, G.J. Harfoot, K.A. Jolliffe, M.D. McLeod, K.J. McRae, S.G. Stewart, M. Vögtle, Chemoenzymatic methods for the enantioselective preparation of sesquiterpenoid natural products from aromatic precursors, Pure Appl. Chem. 75 (2003) 223-229. 1) D.R. Boyd, N.D. Sharma, Enzymatic and chemoenzymatic synthesis of arene transdihydrodiols, J. Mol. Catal. B Enzym. 19-20 (2002) 31-42. m) D.R. Boyd, N.D. Sharma, C.C.R. Allen, Aromatic dioxygenases: Molecular biocatalysis and applications, Curr. Opin. Biotechnol. 12 (2001) 564-573. n) T. Hudlicky, D. Gonzalez, D.T. Gibson, Enzymatic dihydroxylation of aromatics in enantioselective synthesis: expanding asymmetric methodology., Aldrichimica Acta. 32 (1999) 35-62. o) D. R. Boyd, G. N. Sheldrake, The dioxygenase-catalysed formation of vicinal cis-diols, Nat. Prod. Rep. 15 (1998) 309. p) T. Hudlicky, J.W. Reed, Advances in Asymmetric Synthesis, in: A. Hassner (Ed.), Adv. Asymmetric Synth., JAI Press, Greenwich, 1995: pp. 271-312. q) S.M. Brown, T. Hudlicky, in: T. Hudlicky (Ed.), Org. Synth. Theory Appl., JAI Press, Greenwich, 1993: pp. 113-176. r) H.A.J. Carless, The use of cyclohexa-3,5-diene-1,2-diols in enantiospecific synthesis, Tetrahedron: Asymmetry. 3 (1992) 795-826. s) D.A. Widdowson, D.W. Ribbons, D.D. Thomas, The use of substituted cyclohexadiene diols as versatile chiral synthons., Janssen Chim. Acta. 8 (1990) 3-9.
} 
${ }^{3}$ Selected literature for use of biocatalysis in synthesis: a) K. Drauz, H. Waldmann, eds., Enzyme Catalysis in Organic Synthesis, Wiley, 2002. b) M. Wink, ed., An Introduction to Molecular Biotechnology. Fundamentals, Methods and Applications., 2nd ed., Wiley-VCH, Weinheim, 2011. c) A.S. Bommarius, B.R. Riebel-Bommarius, Biocatalysis, 1st ed., Wiley-VCH, Weinheim, 2004. d) C.-H. Wong, G.M. Whitesides, Tetrahedron Organic Chemistry Series Volume 12 Enzymes in Synthetic Organic Chemistry, 1st ed., Academic Press, 1994. e) C.-H. Wong, G.M. Whitesides, Tetrahedron Organic Chemistry Series Volume 12 - Enzymes in Synthetic Organic Chemistry, 1st ed., Academic Press, 1994. f) K. Faber, W.-D. Fessner, N. Turner, eds., Science of Synthesis: Biocatalysis in Organic Synthesis Vol. 1, 1st ed., Thieme, 2015.

${ }^{4}$ M.A. Endoma, V.P. Bui, J. Hansen, T. Hudlicky, Medium-Scale Preparation of Useful Metabolites of Aromatic Compounds via Whole-Cell Fermentation with Recombinant Organisms, Org. Process Res. Dev. 6 (2002) $525-532$.

${ }^{5}$ B. Trost, The atom economy--a search for synthetic efficiency, Science, 254 (1991) 1471-1477.

${ }^{6}$ T. Hudlicky, D.A. Frey, L. Koroniak, C.D. Claeboe, L.E. Brammer Jr., Toward a 'reagent-free' synthesis, Green Chem. 1 (1999) 57-59.

${ }^{7}$ D. Sebrão, M.M. Sá, M.D.G. Nascimento, Regioselective acylation of d-ribono-1,4-lactone catalyzed by lipases, Process Biochem. 46 (2011) 551-556.

${ }^{8}$ K. Faber, Biotransformations in Organic Chemistry, 6th ed., Springer Berlin Heidelberg, Berlin, Heidelberg, 2011.

9 M.E. Peterson, R.M. Daniel, M.J. Danson, R. Eisenthal, The dependence of enzyme activity on temperature: determination and validation of parameters, Biochem. J. 403 (2007) 615.1-615.

${ }^{10}$ O. Kirk, F. Bjorkling, S.E. Godtfredsen, Process for preparing peroxycarboxylic acids using lipase in a non-aqueous medium, US5541092A, 1994.

${ }^{11}$ J.M.R. da Silva, M. da G. Nascimento, Chemoenzymatic epoxidation of citronellol catalyzed by lipases, Process Biochem. 47 (2012) 517-522.

${ }^{12}$ T. Hudlicky, C.D. Claeboe, L.E. Brammer, L. Koroniak, G. Butora, I. Ghiviriga, Use of Electrochemical Methods as an Alternative to Tin Reagents for the Reduction of Vinyl Halides in Inositol Synthons, J. Org. Chem. 64 (1999) $4909-4913$.

13 T. Hudlicky, K. Oppong, C. Duan, C. Stanton, M.J. Laufersweiler, M.G. Natchus, Chemoenzymatic synthesis of functionalized cyclohexylglycines and $\alpha$-methylcyclohexylglycines via Kazmaier-Claisen rearrangement, Bioorg. Med. Chem. Lett. 11 (2001) 627-629.

${ }^{14}$ L. Ingrassia, F. Lefranc, J. Dewelle, L. Pottier, V. Mathieu, S. Spiegl-Kreinecker, S. Sauvage, M. El Yazidi, M. Dehoux, W. Berger, E. Van Quaquebeke, R. Kiss, Structure-activity relationship analysis of novel derivatives of narciclasine (an Amaryllidaceae isocarbostyril derivative) as potential anticancer agents, J. Med. Chem. 52 (2009) 1100-1114.

${ }^{15}$ G. Tibhe, M. Macías, V. Schapiro, L. Suescun, E. Pandolfi, General Method for the Synthesis of (-)-Conduritol C and Analogs from Chiral Cyclohexadienediol Scaffolds, Molecules. 23 (2018) 1653.

${ }^{16}$ M. Dlugosch, X. Ma, S. Yang, M.G. Banwell, C. Ma, J.S. Ward, P. Carr, Syntheses of Structurally and Stereochemically Varied Forms of C7N Aminocyclitol Derivatives from Enzymatically Derived and Homochiral cis -1,2-Dihydrocatechols, Org. Lett. 20 (2018) 7225-7228.

${ }^{17}$ A. Patti, C. Sanfilippo, M. Piattelli, G. Nicolosi, Enantioselective synthesis of (-)- and (+)-conduritol F via enzymatic asymmetrization of cis-cyclohexa-3,5-diene-1,2-diol, J. Org. Chem. 61 (1996) 6458-6461.

18 J.-N. Heo, E.B. Holson, W.R. Roush, Common-Intermediate Strategy for Synthesis of Conduritols and Inositols via $\beta$ Hydroxy Cyclohexenylsilanes, Org. Lett. 5 (2003) 1697-1700. 